\title{
Executive Equity Incentives, Overconfidence and Corporate Inefficient Investment
}

\author{
Sisi Xiong \\ School of Business Administration, South China University of Technology, Guangzhou, China \\ Email: 870076558@qq.com
}

How to cite this paper: Xiong, S.S. (2019) Executive Equity Incentives, Overconfidence and Corporate Inefficient Investment. Open Journal of Business and Management, 7, 209-228. https://doi.org/10.4236/ojbm.2019.71015

Received: December 4, 2018

Accepted: January 8, 2019

Published: January 11, 2019

Copyright (c) 2019 by author(s) and Scientific Research Publishing Inc. This work is licensed under the Creative Commons Attribution International License (CC BY 4.0).

http://creativecommons.org/licenses/by/4.0/

\section{cc) (7) Open Access}

\begin{abstract}
In the past research on equity incentives, the influence of incentive system on individual psychological factors was often neglected. From the perspective of behavioral company finance, this paper takes executives from 2010 to 2016 China A-share listed companies as research samples to research framework for overconfidence, executive equity incentives, and corporate inefficient investment. The results of the study show that equity incentives can alleviate the underinvestment behavior of executives by influencing executives' overconfidence, and executive overconfidence is partly a sub-mediating effect. However, for over-invested enterprises, the indirect effect of executive over-confidence generated by equity incentives on corporate over-investment is a deterioration, and the direct effect of equity incentives is opposite to the indirect effect. So executives' overconfidence in equity incentives, in the excessive investment of enterprises, plays a special mediating effect-the cover effect.
\end{abstract}

\section{Keywords}

Executive Equity Incentives, Executive Overconfidence, Non-Efficiency Investment, Masking Effect

\section{Introduction}

In recent years, investment-driven economic development models have been widely criticized, and as the scale of investment in fixed assets continues to rise, investment efficiency has continued to decline. The low efficiency of macro investment is reflected at the micro level, indicating the problem of investment efficiency at the enterprise level in China. As a participant in the socialist market economy, enterprise investment plays an indispensable role in the total social investment. Therefore, the investment efficiency at the enterprise level deter- 
mines the overall investment efficiency of the society. In recent years, the investment scale of China's A-share listed companies has been increasing, but the investment efficiency has also declined year by year. The low efficiency of investment is manifested in the form of over-investment and under-investment. Over-investment refers to the fact that in the case of free cash flow, the executives invest in those who cannot bring incremental income to the company for personal reasons. Insufficient investment is due to the risk avoidance behavior of shareholders and executives, and on the other hand, in those enterprises with financing constraints, because of the lack of funds, they have to give up some projects that can bring incremental profits to enterprises.

Over-investment and under-investment of enterprises seriously hinder the improvement of corporate value. Therefore, it is extremely urgent to study the mechanism of non-efficiency investment constraints. By closely linking the manager's salary income with the company's performance, it can alleviate the excessive investment caused by the agency problem, and can alleviate the insufficient investment of the enterprise caused by different risk preferences and financing constraints. Chu used data from listed companies in Malaysia to study the relationship between executive compensation, earnings management and excessive investment. This paper argues that there is an endogenous correlation between executive compensation and overinvestment, but the pursuit of overinvestment strategy by executive directors with company equity usually leads to the decline of equity value [1]. Sawers [2], Shen [3] and Chen Xiaodong [4] mainly studied the situation of insufficient $R \& D$ investment caused by the fact that equity incentive alleviates the risk aversion characteristics of managers, and regarded the increase of capital investment and R \& D investment level promoted by equity incentive as the improvement of investment efficiency [5]. In the construction of the manager's salary system, equity incentives are increasingly favored by listed companies, and the wealth that the equity incentives bring to the management is gradually increasing. From the official launch of equity incentives in 2006 to the end of 2016, China's A-share listed companies announced a total of 1374 equity incentive plans. In general, the enthusiasm of China's listed companies to implement equity incentive plans has rapidly increased.

In the past studies on executive equity incentives and corporate inefficient investment, most of them are based on the traditional relationship between the two under the principal-agent theory framework. There is an implicit assumption in this study that all parties involved are rational status. The behavioral finance theory that has emerged in recent years believes that the parties involved in the company's business activities are not completely rational, and the equity incentive mechanism assumes that the behavior pattern of the person is completely in line with the "completely rational economic man" hypothesis in the traditional principal-agent theory, while ignoring the more realistic situation of "incompletely rational economic man" of the system-related participants. 
Studies by past scholars have shown that the design of the salary system will affect the manager's overconfidence mentality. Overconfidence is a kind of cognitive bias, which refers to the tendency of excessive exaggeration of private information due to limited rationality and cognitive bias. As the company's main decision-makers, the management team often overestimates the project's revenue and underestimates the project's investment risk when it comes to the risk and benefit trade-offs. This cognitive bias will lead to decision-making deviation from the company. So what role does the executive overconfidence caused by equity incentive play in the relationship between equity incentive and inefficient investment? Does executive overconfidence play different roles in executive equity incentives, overinvestment and underinvestment? This paper will relax the rational human premise in the traditional principal-agent theory, and try to explore the relationship between executive equity incentives and corporate inefficient investment from the perspective of behavioral company finance.

\section{Literature Reviews}

\subsection{The Impact of Executive Equity Incentives on Insufficient Investment in Enterprises-Based on the Mediating Effect of Executive Overconfidence}

Different risk preferences and financing constraints are the main reasons for the lack of investment in listed companies in China. First, Milgrom first analyzed from the perspective of risk-taking. Shareholders can reduce the overall risk by diversifying investment and thus appear to be risk-neutral, and managers can not disperse their own risk-taking characteristics, making them appear more obvious risks evasion tendency [6]. Aghion believes that managers' risk from corporate investment is not equal to the benefits they receive, which leads managers to abandon better investment projects in many cases, so managers may like to enjoy a quiet life. Rather than being keen on expanding the company's size, investing in new projects will increase their responsibilities and require managers to pay more working hours, so managers will be reluctant to invest in new projects based on personal self-interest [7]. In addition, the theory of information asymmetry believes that compared with investors, enterprise managers have more information about business operations, and investors' inadequate understanding of corporate information may lead to poor project financing, which hinders the process of investment projects and results in insufficient investment [8]. Finally, it is worth noting that in recent years, China's listed companies have seen another kind of investment "chaos". In 2016, a total of 890 listed companies in A-shares purchased wealth management products, with a total financial income of 1.07 trillion yuan. Revenue has gradually become a strong pillar of the performance of some listed companies, and even the company's "life-saving straw" to turn losses into profits. Listed companies do not think about how to improve the long-term sustainable development of enterprises when their main business is in a loss state, but they are overly dependent on investment and 
wealth management products, mostly because of the pursuit of short-term interests by executives.

The implementation of the equity incentive system can alleviate the underinvestment of enterprises. First of all, equity incentives have solved the situation of unbalanced risk and return of executives to a certain extent, and weakened the risk aversion tendency of management. When increasing the income from the company's capital investment enables managers to obtain more personal benefits, the interests of management and shareholders will become more consistent. Managers will be more enthusiastic about increasing self-work time and energy. Proper investment projects, increase investment scale to get returns. Past scholars' research results also show that executive equity incentives can alleviate conflicts of interest between executives and shareholders, and improve corporate investment levels [9] [10] [11] [12] [13]. Secondly, equity incentives can also alleviate the financing constraints of enterprises to a certain extent. Leland found that equity incentives have the function of signal transmission, and by releasing good news to the capital market, the financing costs caused by information asymmetry can be reduced. Zhang Dunli also confirmed this conclusion using data from China. In addition, equity incentives have also somewhat relieved the company's pressure on executives' cash compensation [14]. Finally, in 2008, the Memorandum on Equity Incentives (II) issued by the China Securities Regulatory Commission explicitly required that the measurement of accounting indicators in equity incentives must be calculated using data after deducting non-recurring gains and losses. This requirement is also limited to some extent. Managers paying too much attention to short-term performance behaviors, or through the use of related transactions to achieve exercise and unlock conditions, can enable managers to develop valuable investment projects based on the company's long-term development, and investment in short-term wealth management products can not help Executives reach the exercise (unlock) bar.

Under the traditional principal-agent framework, the design of compensation contracts is designed to alleviate agency problems through incentives, and encourage managers to work to maximize company value. Equity incentives are increasingly used as incentives for incentives. In the course of this research, the impact of corporate equity incentives on managerial psychology is neglected. Psychological research found that past successes and other forms of positive feedback can enhance a person's self-esteem and self-confidence [12] [15], extending to the field of management, pay behavior view that compensation is an important reason that affects managers' cognitive bias. Not only high salary can give managers positive feedback, other forms of salary incentives such as equity incentives will also It affects the cognitive path of executives. Therefore, in the process of designing the salary system, we should pay more attention to the impact on managers' psychology and the economic consequences of managers' cognitive bias.

This paper argues that granting executive equity incentives can lead executives 
to over-confidence. First of all, when determining the incentive target, the equity incentive plan generally selects those employees who have loyal to the company for a long time in the past or have made special contributions to the company. The share of the employee's equity incentive can also be regarded as a certain degree. To a certain extent, the share of equity incentive granted to employees can also be regarded as the affirmation of the previous work of employees and the higher expectations placed on employees [16] [17]. Previous scholars believe that the potential factors affecting managers' overconfidence include past success, external appreciation of managers, and self-importance of managers. The share of equity incentives given to executives can easily lead to overconfidence of executives. Secondly, the granting of executive equity incentives means that the expected pay gap between the motivated target and other executives who are not granted equity incentives will widen. It is expected that the larger pay gap will be interpreted by the manager as what the organization has done for itself. The compensation of contribution is the recognition of the organization's ability and the recognition of its shareholder value. It is a positive feedback on its own ability. Therefore, the manager will become more confident. When the confidence level exceeds a certain threshold, it will be Excessive self-confidence [18]. Executives will even see the expected increase in the pay gap as an indication of the importance of their abilities and positions, which will also lead to overconfidence of managers [19]. Previous scholars also used executive pay gaps as proxy variables for overconfidence, such as Brown [20], Zhang Zhengtang [21] and Jiang Fuxiu [22] and other scholars use the ratio of the top three executive compensations to the total executive compensation to measure the degree of overconfidence. Finally, China's equity incentive plan is generally divided into three phases. If the first or even the second phase of the equity incentive plan is successfully exercised or unlocked, it will not only enhance the executives' sense of achievement in the company's performance creation, but also enhance the executives. The influence of other employees in the company's minds, and even under certain circumstances, can enhance executives' voice and partial rights in the company, and encourage executives' overconfidence to continue to increase.

The overconfidence of managers caused by the granting of executive equity incentives will alleviate the underinvestment of enterprises. The manager's psychological cognition is ultimately reflected in his organizational behavior, and is reflected in the process of investment decision-making for the manager of the enterprise. For under-investment companies, executive over-confidence caused by the granting of executive equity incentives will increase the level of risk taking of executives. Executives with higher risk appetites will relax their harsh conditions for project review, which will increase the company's investment level and alleviate the lack of investment. Therefore, managers' overconfidence is manifested as a mediating effect in equity incentives and corporate investment deficits. Because the main effect of equity incentives on corporate investment is also significant, the mediating effect of overconfidence is represented as partial intermediary. 
Hypothesis 1: Managers' overconfidence appears as a partial mediating effect in executive equity incentives and corporate investment deficiencies

\subsection{The Impact of Executive Equity Incentives on Over-Investment in Enterprises-Based on the Covering Effect of Executive Overconfidence}

The agency problem is the main reason for the excessive investment of listed companies in China. The characteristics of short-term behavior of managers in the management of the company are more obvious. What they pursue is generally the maximization of personal wealth during their tenure. This gives executives a strong incentive to increase corporate capital investment. According to modern agency theory, executives who control the company are more likely to over-invest, because they can build for themselves by building a "corporate empire", high salary, allowance and personal reputation [23] [24]. This kind of inefficient investment behavior in order to expand the scale of the enterprise is largely a financial decision made by the manager to further consolidate and strengthen his control rights [25].

And this irrational behavior can be restrained by setting relevant incentives and supervision mechanisms, while equity incentive mechanism is the most commonly used and most controllable method, which can constrain the deviation of manager behavior caused by uncertain environment. Function [2] [12] [26]. First of all, equity incentives are conducive to coordinating conflicts of interest between managers and shareholders. Because managers themselves also hold stocks of companies, managers and shareholders are a risk-sharing and benefit-sharing relationship. Decision-making based on the principle of maximizing the long-term interests of shareholders can reduce short-term profit-seeking behavior, thus reducing agency problems between managers and shareholders, and reducing agency costs [11] [27]. Granting managers certain rights and incentives can link personal self-interest with corporate wealth, so that managers can share the residual income of the company. Managers will consider the long-term contribution of investment to the company's value when using funds, not just short-term. Secondly, the company's implementation of equity incentives can effectively stimulate the enthusiasm of managers, and make them work hard to improve the company's performance, and can also reduce the irrational behavior of managers' investment decisions. Thirdly, the period of equity incentive plan implemented by listed companies in China is generally about 3 years. If the senior executives leave their jobs during this period, the equity incentive share owned by the executives will automatically become invalid. Therefore, the equity incentives will help lower the executives. The turnover rate is expected to extend the term of the executives, former scholars such as Wu Lianghai [28] and Lin Chaonan [29] Research by scholars such as found that as the executive's tenure is extended, its strategy and decision-making will be more sensible. Generally speaking, short-term executives will pay more attention to short-term interests. Long-term executives will be more interested 
in their own and long-term interests, thus reducing inefficient investment behavior. At the same time, with the extension of the term of the executives, the speed and quality of information exchange between the members of the enterprise will be greatly improved, so that high-quality information can be effectively obtained from the organization to make the most correct decision-making, and the work efficiency is improved. At the same time, it also promotes the improvement of corporate efficiency. Finally, by studying the stock option exercise conditions and the restricted stock unlocking conditions in the implementation of the equity incentive plan of listed companies in China, it can be found that listed companies pay more attention to the growth of income (such as net profit and net profit growth rate) when setting conditions. And the return on net assets, etc.), few companies will only focus on the increase in the size of the company (operating income, operating income growth rate, etc.), if the manager increases the scale of business income through excessive investment, but the profit situation is not As income grows, it is difficult to achieve the exercise conditions of stock options or the unlocking conditions of restricted stocks, and personal wealth will also be affected. In order not to adversely affect the company's performance, if the project has no special investment value, the manager will not choose an investment project with NPV $<0$. Indicators that are oriented toward the company's business performance will encourage managers to focus more on operational efficiency than on building a corporate empire.

Similar to the above, the implementation of equity incentives for executives will lead to overconfidence among executives. Over-confident managers tend to overestimate future cash inflows and underestimate the discount rate of projects when analyzing investment projects. As a result, the illusion of a large net present value of the project, the overconfident manager has a stronger willingness to invest in expansion than the rational manager [30]. Secondly, overconfident managers tend to overestimate the accuracy of private information and the correctness of their own decisions, underestimate the possibility of failure of investment decisions, and over-trust the results of matters such as corporate investment decisions [31] [32]. Finally, the exercise (unlock) conditions required by the equity incentive plan are accompanied by requirements for the company's performance growth and net profit growth. In order to achieve higher performance growth, executives will inevitably seek new ways of business growth, including expanding investment. The scale is an effective way to achieve the exercise conditions, and the overconfident managers are blindly investing in the project in order to achieve performance growth based on the over-optimistic belief in the project, and the investment in this case is much more. The land is a phenomenon that damages the value of the company and is manifested as excessive investment.

The overconfidence of managers and the over-investment of enterprises are negatively correlated. That is, the path of equity incentives affecting excessive investment by enterprises may weaken the direct mitigation effect of equity incentives on excessive investment, thus showing the "masking effect". The mask- 
ing effect is a special case of the mediating effect. In the model, the direct effect is opposite to the indirect effect regression coefficient [33]. Based on the above inference, this paper argues that managers' overconfidence shows a hidden effect in the mechanism of equity incentives and over-investment. In the past, there were more important mediating effects in the study of equity incentives and over-investment, which were not included in the study. The following assumptions are made:

Hypothesis 2: Managers' overconfidence appears as a cover-up effect in executive equity incentives and corporate over-investment.

\section{Research Design}

\subsection{Data}

This paper selects China's A-share listed companies as research objects from 2010 to 2016. In addition, this paper considers the year distribution characteristics of the actual incentive effect of equity incentives, and determines the specific year distribution of the equity incentive effect according to the distribution of equity incentive unlocking (exercise) years disclosed in the company's enactment of equity incentives. In addition, ST, ${ }^{\star} \mathrm{ST}$, and financial listed companies were excluded from the sample, and the companies that terminated the equity incentive plan were excluded. The total number of over-investment samples determined by the company was 5188 , among them, there are 774 samples that implement equity incentive, accounting for $14.92 \%$ of the total number of samples; the total number of overconfidence samples was 773, accounting for $14.90 \%$ of the total number of samples. And the number of under-investment samples was 10,588, among them, there are 1562 samples that implement equity incentive, accounting for $15.28 \%$ of the total number of samples; the total number of overconfidence samples was 1490 , accounting for $14.52 \%$ of the total number of samples. The data in this paper is derived from WIND software, and the relevant variables of equity incentives are obtained by manually collecting the equity incentive drafts issued by listed companies.

\subsection{Model}

Drawing on the procedure proposed by Wen Zhonglin [28], this paper constructs the following recursive model to test the masking effect of overconfidence.

$$
\begin{aligned}
\text { OVERINV }_{i, t}\left(\mathrm{UNDERINV}_{i, t}\right)= & \beta_{00, \text { nian }}+\beta_{10, \text { nian }} \mathrm{EI}_{-} \mathrm{ALL}_{i . t}+\sum \text { Control } \\
& +\sum \text { Industry }+\sum \mathrm{Year}+\varepsilon_{i, t} \\
\mathrm{OC}_{i, t}=\beta_{00, \text { nian }}+\beta_{20, \text { nian }} \mathrm{EI}_{-} \mathrm{ALL}_{i . t} & +\sum \mathrm{Control}+\sum \text { Industry }+\sum \mathrm{Year}+\varepsilon_{i, t} \\
\text { OVERINV }_{i, t}\left(\mathrm{UNDERINV}_{i, t}\right)= & \beta_{00, \text { nian }}+\beta_{30, \text { nian }} \mathrm{EI}_{-} \mathrm{ALL}_{i . t}+\beta_{40, \text { nian }} \mathrm{OC}_{i, t} \\
& +\sum \text { Control }+\sum \text { Industry }+\sum \mathrm{Year}+\varepsilon_{i, t}
\end{aligned}
$$

Model 3.1 and Model 3.3 are multiple linear regressions, and model 3.2 is bi- 
nary logistic regression.

The inspection procedures for the over-confidence of executives in the incentive effect of executive equity incentives and corporate investment are as follows:

If the coefficient $\beta_{10 \text {,nian }}$ is significantly positive, it shows that equity incentive can indeed alleviate the underinvestment behavior of enterprises; secondly, the model (3.2) is regression, if the coefficient $\beta_{20 \text {,nian }}$ is positive, it shows that equity incentive will lead to overconfidence of managers; finally, the model (3.3) is regression, if the direct effect $\beta_{30 \text {,nian }}$ and indirect effect of executive equity incentive on underinvestment of enterprises. $\beta_{40 \text {,nian }}$ should be the same, indicating that executive equity incentives play a part of the intermediary role in executive overconfidence and underinvestment.

Executives' overconfidence test procedures for the cover-up effect of executive equity incentives and corporate over-investment are as follows:

First, regression analysis is performed on the model (3.1), if the variable $\beta_{10 \text {,nian }}$. The coefficient is significantly negative, which indicates that the equity incentive can indeed alleviate the excessive investment behavior of the enterprise; secondly, the model (3.2) is returned if $\beta_{20 \text {,nian }}$. The coefficient is positive, indicating that equity incentives will lead to over-confidence in managers; finally, regression on model (3.3), if variables $\beta_{30 \text {,nian }}$ with $\beta_{40 \text {,nian }}$. Both are significant $\beta_{30 \text {,nian }}$. The coefficient is negative $\beta_{40 \text {,nian }}$. The positive coefficient indicates that the equity incentive will affect the over-investment level of the enterprise by acting on the manager's overconfidence, and this indirect effect is manifested as the "masking effect", that is, the direct effect of equity incentives on over-investment ( $\beta_{30 \text {,nian }}$ Coefficient) and indirect effects ( $\beta_{40 \text {,nian }}$ Coefficient) The opposite sign, the case where the total effect is obscured. The existence of the "masking effect" indicates that there are other significant intermediate variables between the independent variable and the dependent variable.

\subsection{Variable Measurement}

\subsubsection{Equity Incentive}

In terms of the intensity of equity incentives, learn from Bergstresser [34]. The method of measuring equity incentives. In this paper, when the company's stock price changes by $1 \%$, the change in the value of the equity incentive share is used to measure the strength of the equity incentives:

$$
\begin{aligned}
\mathrm{INV}_{i, t}= & \beta_{10, \text { nian }}+\beta_{20, \text { nian }} \mathrm{GROWTH}_{i, t-1}+\beta_{3} \mathrm{CASH}_{i, t-1}+\beta_{4} \mathrm{LEV}_{i, t-1}+\beta_{5} \mathrm{LNASSET}_{i, t-1} \\
& +\beta_{6} \mathrm{AGE}_{i, t-1}+\beta_{7} \mathrm{RETURN}_{i, t-1}+\beta_{7} \mathrm{INV}_{i, t-1}+\sum \text { industry }+\varepsilon_{i, t}
\end{aligned}
$$

In the model, EI_ALL ${ }_{i . t}$ represents the company's total number of executive incentives for executives at the beginning of the year, including stock options and restrictions on new stocks. price i,t-1 $_{1}$ For the company stock price at the beginning of the year, Rstock ${ }_{i, t-1}$ For the incentive share of the restricted stocks involved in the company at the beginning of the year, Options ${ }_{i, t-1}$. For the incentive share of the company's executive stock options at the beginning of the year, UNRstock Unt $_{i, 1}$. The total number of unrestricted shares held by all senior 
executives at the beginning of the year, Cashpay ${ }_{i, t-1}$. The total amount of cash compensation received by the company's senior executives in the company that year, EI_ALL $L_{i, t-1}$. The higher the value, the greater the effect of equity incentives.

Different from the previous scholars' research, after reading the specific rules of the publicly disclosed equity incentive drafts of listed companies, it is found that the unlocking period of stock options often involves 3 years or more, and the annual unlocking rights are different after the annual exercise conditions are satisfied. The years are roughly equal. For the Eastern Communications Equity Incentives in Table 1, the incentive shares in 2014, 2015, and 2016 accounted for $30 \%, 30 \%$, and $40 \%$ of the total. This paper believes that the incentive effect of equity is not only the first year of specific incentives for stock incentives. According to the distribution of the unlocking period of the exercise, Oriental Communications' equity incentive plan has corresponding incentives in 2014, 2015 and 2016. So in 2014 the company's Options ${ }_{i, t-1}$. In order to motivate the total amount of ${ }^{\star} 30 \%, 2015$ is the total incentive amount ${ }^{\star} 30 \%$, and 2016 is the total incentive amount ${ }^{\star} 40 \%$.

In addition, the research object of this paper is the equity incentive of the entire senior management team. Different from the previous scholars, the research object is limited to the CEO. This paper believes that the relevant investment decisions of listed companies are determined by the senior management team, not just the CEO. Individually, the opinions of the executive team will affect each other, and the opinions of other executives will directly or indirectly affect the investment decisions through the CEO. However, different executives have different influences on investment decisions. However, high-impact executives are generally awarded a higher share of equity incentives, thus playing a weighting effect to better measure the entire executive team.

\subsubsection{Insufficient Investment in Enterprises and Excessive Investment by Enterprises}

This article draws on Richadson [35]. The method of over-investing in enterprises, this article will $\mathrm{INV}_{i, t}$. Defined as the increase in the company's investment in the current year, the growth rate of operating income $\left(\mathrm{GROWTH}_{i, t-1}\right)$ is selected

Table 1. Regression model involves variables.

\begin{tabular}{|c|c|c|}
\hline Variable name & Variable symbol & Variable definitions \\
\hline \multicolumn{3}{|c|}{ Explained variable } \\
\hline Insufficient investment & UNDERINV $_{i, t}$ & Model calculation \\
\hline Over-investment & OVERINV $_{i, t}$ & Model calculation \\
\hline \multicolumn{3}{|c|}{ Explanatory variables } \\
\hline Total intensity of equity incentives & EI_ALL ${ }_{i, t}$ & Model calculation \\
\hline Equity incentive dummy variable & EI_dum ${ }_{i, t}$ & $\begin{array}{l}\text { It has } 1 \text { equity incentive effect in the year, } \\
\text { otherwise it is } 0 .\end{array}$ \\
\hline Executive overconfidence & $\mathrm{OC}_{i, t}$ & Overconfidence is 1 , otherwise 0 \\
\hline
\end{tabular}


as an indicator to measure the company's growth opportunities. Other control variables include cash holdings $\left(\mathrm{CASH}_{i, t-1}\right)$ and asset-liability ratio $\left(\mathrm{LEV}_{i, t-1}\right.$. $)$, firm size (LNASSET $\left.{ }_{i, t-1}\right)$, age of listing $\left(\mathrm{AGE}_{i, t-1}\right)$, and stock return $\left(\operatorname{RETURN}_{i, t-1}\right)$, as well as controlling industry dummy variables.

In this paper, the data from 2006 to 2016 are used for regression, and the fixed effect of the industry is controlled. In order to reduce the influence of outliers on the regression results, this paper performs the tailing processing of the variable values from $1 \%$ to $99 \%$, and performs the variable data. Centralized processing, and finally the residual of the regression model is used as a substitute for the non-efficiency investment of the enterprise. If the residual is greater than zero, it is the level of excessive investment of the enterprise. If the residual is less than zero, it is the level of insufficient investment.

\subsubsection{Executives are Overconfident}

This paper uses the corporate profit forecast deviation method to measure the overconfidence of the senior management team. The listed company information disclosure system requires disclosure of the performance forecast for the current year in the third quarter report. If the enterprise forecasts the current year's profit level to differ by more than $50 \%$ from the actual situation, then the company's executive team was considered overconfident in the year and assigned a value of 1 . In the current performance forecast disclosed by listed companies, the forecasted profit level generally has a general range. This paper compares the actual net profit growth rate with the predicted profit level and the worst case average net profit growth rate. A net profit growth rate of less than $50 \%$ of the projected net profit growth rate is considered a sample of overconfidence. For example, Xinpeng's 2015 third quarter report disclosed a net profit of about 85.827 million yuan to $119,586,700$ yuan, an increase of $0 \%$ to $35 \%$. In 2015 , the actual net profit growth rate of Xinpeng shares was $-3.12 \%$, and the average forecast growth rate was $17.5 \%$ differs by $117.84 \%$, which is greater than $50 \%$, so this year's executive team is set as a sample of overconfidence.

The summary of the variables involved in the paper is shown in Table 1.

\section{Results}

This study selects companies with over-investment characteristics, so for a particular company, there may be different investment characteristics (over-investment or under-investment) between 2010 and 2016, and it is not suitable for panel The data is subjected to regression analysis, so the data processing in this chapter treats the sample data as mixed cross-section data for regression, and adds annual dummy variables to control the time effect in the regression model.

Secondly, considering the heteroscedasticity problem, the Robust option is used in the data processing of the stata analysis software. The regression processing after the paper uses the modified heteroscedastic regression model. Again, in order to avoid the influence of abnormal discrete values, this paper performs $1 \%$ Winzorize processing on all continuous variables in the regression. 
Table 2 shows the test regression results of executives' overconfidence in the intermediary effect of executive equity incentives and corporate investment. The regression results of Modell show that the estimated coefficient of total equity incentives $\left(\mathrm{EI}_{-} \mathrm{ALL}_{i, t}\right)$ is significantly positive at $1 \%$, indicating that the implementation of executive equity incentives can alleviate the underinvestment behavior of enterprises. Model 3 shows that the total intensity of equity incentives $\left(\mathrm{EI}_{-} \mathrm{ALL}_{i, t}\right)$ and the coefficient of overconfidence of executives are significantly positive at $5 \%$, indicating a significant positive correlation between equity incentives and executive overconfidence, i.e. giving Executives' equity incentives can cause executives' overconfidence, and the more shares they give to equity incentives, the greater the likelihood that executives will be overconfident. Model6 adds equity incentives and executive overconfidence variables to the regression model of under-investment in the enterprise. Manager overconfidence $\left(\mathrm{OC}_{i, t}\right)$ is significantly positive at $1 \%$, the estimated coefficient is 0.1072 , and the total intensity of equity incentives. The estimated coefficient is negative at the level of $1 \%$, and the estimated coefficient is 0.0278 . Therefore, the direct effect of the total intensity of equity incentives on excessive investment of enterprises is 0.0278 . The indirect effect of the total intensity of equity incentives on over-investment of enterprises is $0.1329 \times 0.1072=0.0142$. The direct incentive effect of the total intensity of equity incentives is the same as the indirect incentive effect, indicating that managers' overconfidence appears as a partial mediating effect in equity incentives and corporate investment deficits.

Second, consider the incentive differences between different equity incentive models. The regression results of Model 2 show that the restricted stock incentive intensity estimation coefficient is significantly positive at $5 \%$, while the regression coefficient of stock option incentive intensity is not significant. Model 4 and Model 7 also show the same result. It shows that in terms of alleviating the lack of investment in enterprises, only the incentives of restricted stocks have a mitigating effect, and the effect of stock options in this respect is not significant. The mediating effect of executive overconfidence on executive equity incentives and corporate investment is mainly Incentive utility in the form of restricted stock. On the one hand, it is related to the sample data volume. After 2012, China's listed companies are more inclined to restrict stocks, which leads to insufficient source of sample data for stock options. On the other hand, from the perspective of incentive risk, restricted stocks have been granted to the motivated target at the beginning of the implementation of the equity incentive plan, and the relevant measures stipulate that the price of the restricted stock is the lowest for the first 20 trading days, $6050 \%$ of the average trading price of a company on a trading day or 120 trading days, and under the stock option system, the exercise price must be 20 trading days, 60 trading days or 120 transactions before the draft of the equity incentive plan is announced. One of the average price of the company's stock trading, the exercise price of the stock option is significantly higher than the discounted price of the restricted stock. Therefore, under the same unlocking (exercise) conditions, due to the characteristics of the restricted 
Table 2. Executives overconfidence mediation effect regression results.

\begin{tabular}{|c|c|c|c|c|c|c|c|}
\hline & \multicolumn{2}{|c|}{ UNDERINV $_{i, t}$} & \multicolumn{2}{|c|}{$\mathrm{OC}_{i, t}$} & \multicolumn{3}{|c|}{ UNDERINV $_{i, t}$} \\
\hline & Model 1 & Model 2 & Model 3 & Model 4 & Model 5 & Model 6 & Model 7 \\
\hline \multirow{2}{*}{ EI_ALL $L_{i, t}$} & $0.0244^{\star *}$ & & $0.1329^{\star *}$ & & & $0.0278^{* *}$ & \\
\hline & $(2.54)$ & & $(2.43)$ & & & $(2.55)$ & \\
\hline \multirow{2}{*}{$\mathrm{EI}_{-} \mathrm{RS}_{i, t}$} & & $0.0262^{\star \star}$ & & $0.1906^{\star \star}$ & & & $0.0289^{* * *}$ \\
\hline & & $(4.25)$ & & $(2.47)$ & & & $(3.42)$ \\
\hline \multirow{2}{*}{ EI_OP ${ }_{i, t}$} & & 0.0157 & & $0.1416^{* *}$ & & & 0.0145 \\
\hline & & (1.33) & & $(2.35)$ & & & $(0.98)$ \\
\hline \multirow{2}{*}{$\mathrm{OC}_{i, t}$} & & & & & $0.1072^{\star * *}$ & $0.1028^{\star * *}$ & $0.1142^{\star * *}$ \\
\hline & & & & & 2.68 & 2.74 & 2.71 \\
\hline \multirow{2}{*}{$\mathrm{CF}_{i, t-1}$} & $0.0673^{*}$ & $0.0619^{*}$ & & & $0.0585^{*}$ & $0.0618^{*}$ & $0.0624^{*}$ \\
\hline & (1.73) & (1.68) & & & 1.69 & 1.72 & 1.74 \\
\hline \multirow{2}{*}{$\mathrm{AMD}_{i, t-1}$} & 0.0122 & 0.0132 & & & 0.0127 & 0.0130 & 0.0129 \\
\hline & $(0.93)$ & $(0.89)$ & & & 0.90 & 0.83 & 0.87 \\
\hline \multirow{2}{*}{ ORA $_{i, t-1}$} & $-0.0452^{\star}$ & $-0.0416^{*}$ & & & $-0.0438^{\star}$ & $-0.0427^{*}$ & $-0.0406^{* *}$ \\
\hline & $(-1.81)$ & $(-1.88)$ & & & -1.66 & $(-1.87)$ & -1.83 \\
\hline \multirow{2}{*}{$\mathrm{LEV}_{i, t-1}$} & $0.2132^{* * *}$ & $0.2253^{* * *}$ & $-0.0425^{\star \star}$ & $-0.0417^{\star \star}$ & $0.2060^{* * *}$ & $0.2152^{* * *}$ & 0.2476 \\
\hline & (6.58) & (6.73) & $(-2.11)$ & $(-2.31)$ & 6.23 & 6.24 & 6.22 \\
\hline \multirow{2}{*}{$\mathrm{SOE}_{i, t-1}$} & $0.3117^{* * *}$ & $0.2923^{\star * *}$ & $-0.0207^{\star * *}$ & $-0.0193^{\star * *}$ & $0.2974^{* * *}$ & $0.2883^{\star * *}$ & $0.2736^{\star * *}$ \\
\hline & $(5.34)$ & (5.49) & $(-4.24)$ & $(-4.15)$ & 5.43 & 5.62 & 5.52 \\
\hline \multirow{2}{*}{$\mathrm{EBD}_{i, t-1}$} & $0.0213^{*}$ & $0.0241^{\star}$ & $-0.0536^{*}$ & $-0.0573^{\star}$ & $0.0237^{\star}$ & 0.0216 & 0.0203 \\
\hline & (1.68) & (1.73) & $(-1.93)$ & $(-1.90)$ & 1.68 & 1.69 & 1.70 \\
\hline \multirow{2}{*}{$\operatorname{SIZE}_{i, t-1}$} & $-0.1170^{* * *}$ & $-0.1273^{* * *}$ & $0.1941^{* * *}$ & $0.1880^{* * *}$ & $-0.1136^{* * *}$ & $-0.1174^{* * *}$ & $-0.1200^{* * *}$ \\
\hline & $(-8.02)$ & $(-7.93)$ & $(3.52)$ & (3.61) & -7.88 & $(-8.14)$ & $(-8.09)$ \\
\hline \multirow{2}{*}{ GROWTH $_{i, t-1}$} & $0.0373^{* * *}$ & $0.0391^{* * *}$ & $0.2722^{\star * *}$ & $0.2826^{* * *}$ & $0.0404^{\star *}$ & $0.0389^{* *}$ & $0.0394^{* *}$ \\
\hline & $(2.61)$ & $(2.73)$ & $(5.74)$ & $(5.69)$ & 2.64 & 2.57 & 2.52 \\
\hline \multirow{2}{*}{$\mathrm{ROE}_{i, t-1}$} & & & $0.0732^{\star \star}$ & $0.0722^{\star \star}$ & & & \\
\hline & & & $(1.84)$ & $(1.82)$ & & & \\
\hline \multirow{2}{*}{$\mathrm{PB}_{i, t-1}$} & & & $-0.1092^{\star}$ & -0.1013 & & & \\
\hline & & & $(-1.83)$ & $(-1.79)$ & & & \\
\hline \multirow{2}{*}{ TURN $_{i, t-1}$} & & & -0.0736 & -0.0711 & & & \\
\hline & & & $(-0.85)$ & $(-0.77)$ & & & \\
\hline \multirow{2}{*}{ cons } & $-0.0521^{\star * *}$ & $-0.0462^{\star * *}$ & $-2.4362^{\star * *}$ & $-2.3255^{\star * *}$ & $-0.0754^{* * *}$ & $-0.0625^{\star * *}$ & $-0.0547^{\star * *}$ \\
\hline & $(-6.25)$ & $(-5.92)$ & $(-5.21)$ & $(-5.33)$ & $(-6.08)$ & $(-6.33)$ & $(-6.52)$ \\
\hline Year & YES & YES & YES & YES & YES & YES & YES \\
\hline Industry & YES & YES & YES & YES & YES & YES & YES \\
\hline $\mathrm{N}$ & 10225 & 10225 & 10225 & 10225 & 10225 & 10225 & 10225 \\
\hline Adj_R $R^{2}$ & 0.1243 & 0.1252 & & & 0.1317 & 0.1284 & 0.1401 \\
\hline $\begin{array}{l}\text { Likelihood } \\
\text { ratio }\end{array}$ & & & $342.3254^{\star}$ & $359.4362^{* * *}$ & & & \\
\hline
\end{tabular}


discounts granted by the restricted stocks, the restricted stocks will have a higher probability of obtaining returns than the stock options after the unlocking (exercise) conditions are met in the future. The risk of stocks is relatively low.

In addition, from the perspective of incentive ability, the rights and obligations of stock options have the characteristics of asymmetry. The executives only have the right to exercise the right to exercise without having to bear the obligation to exercise. Therefore, stock options are only incentive and not punitive. When the exercise condition is reached or the stock price falls below the exercise price, the holder of the equity option will choose to give up the exercise and will not incur substantial losses. Restricted stocks have a series of penalties for executives. Executives need to pay a monetary sum to buy stocks when they are granted restricted stock. If the unlocking conditions are not met, the company will buy back the stock at the price. The executives are responsible for the loss of time cost of cash. Or if the stock price is lower than the purchase cost of the stock after the unlock condition is met, the holder will also cause actual loss of wealth. The rights and obligations of restricted stocks are equal, so restricted stocks are both motivating and punitive.

Therefore, compared with stock options, restricted stocks are more motivating for executives to meet various unlocking conditions to maximize their own interests. The characteristics of all aspects of the restricted stock and stock options can be found that the incentives for equity options are lower than those for restricted stocks.

Table 3 shows the test regression results of executive overconfidence in executive equity incentives and corporate over-investment masking effects. The Model 2 results show that the estimated coefficient of total equity incentive strength $\left(\mathrm{EI}_{-} \mathrm{ALL} \mathrm{L}_{i, t}\right)$ is significantly negative at $1 \%$, indicating that the implementation of equity incentives can alleviate the excessive investment behavior of enterprises. Model 3 shows that the estimated coefficient of equity incentive total variable $\left(\mathrm{EI}_{-} \mathrm{ALL}_{i, t}\right)$ is significantly positive at $5 \%$, indicating that there is a significant positive correlation between equity incentives and executive overconfidence, that is, giving executive equity incentives will cause The overconfidence of executives. Model 6 demonstrates the results of multiple regression analysis of total equity incentive intensity and manager overconfidence $\left(\mathrm{OC}_{i, t}\right)$ over-investment $\left(\mathrm{OVERINV}_{i, t}\right)$. Manager overconfidence $\left(\mathrm{OC}_{i, t}\right)$ is significantly positive at $1 \%$, the estimated coefficient is 0.138 , the estimated coefficient of total equity incentive is negative at $1 \%$, and the estimated coefficient is -0.0474 , so equity incentive The direct effect of total intensity on over-investment of enterprises is -0.0474 . The indirect effect of the total intensity of equity incentives on over-investment of executives is $0.1437 \times 0.138=0.0198$. The direct incentive effect of the total intensity of equity incentives is opposite to that of indirect incentives. It shows that managers' overconfidence appears as a "masking effect" between equity incentives and corporate over-investment, and Hypothesis 2 is proved.

Through the analysis of the above empirical results, it can be seen that equity incentives will have an overconfidence tendency by giving positive feedback to 
Table 3. Executives overconfidence masking effect regression results.

\begin{tabular}{|c|c|c|c|c|c|c|c|}
\hline & \multicolumn{2}{|c|}{ OVERINV $_{i, t}$} & \multicolumn{2}{|c|}{$\mathrm{OC}_{i, t}$} & \multicolumn{3}{|c|}{ OVERINV $_{i, t}$} \\
\hline & Model 1 & Model 2 & Model 3 & Model 4 & Model 5 & Model 6 & Model 7 \\
\hline \multirow{2}{*}{ EI_ALL $L_{i, t}$} & $-0.0366^{* * *}$ & & $0.1437^{\star *}$ & & & $-0.0474^{\star * x}$ & \\
\hline & $(-3.47)$ & & $(2.36)$ & & & $(-3.58)$ & \\
\hline \multirow{2}{*}{$\mathrm{EI}_{-} \mathrm{RS}_{i, t}$} & & $-0.3885^{\star * *}$ & & $0.1523^{* *}$ & & & $-0.0492^{* * *}$ \\
\hline & & $(-4.26)$ & & $(2.41)$ & & & $(-4.57)$ \\
\hline \multirow{2}{*}{ EI_OP ${ }_{i, t}$} & & -0.2869 & & $0.1416^{* *}$ & & & -0.2762 \\
\hline & & $(-1.14)$ & & (2.33) & & & $(-1.23)$ \\
\hline \multirow{2}{*}{$\mathrm{OC}_{i, t}$} & & & & & $0.136^{* * *}$ & $0.138^{\star * *}$ & $0.138^{* * *}$ \\
\hline & & & & & -3.00 & -3.04 & -3.05 \\
\hline \multirow{2}{*}{$\mathrm{CF}_{i, t-1}$} & $0.0422^{\star *}$ & $0.0444^{* *}$ & & & $0.0122^{* *}$ & $0.0125^{*}$ & $0.0132^{*}$ \\
\hline & -2.32 & -2.44 & & & -2.27 & -1.77 & -1.81 \\
\hline \multirow{2}{*}{$\mathrm{AMD}_{i, t-1}$} & 0.0122 & 0.013 & & & $0.0417^{* *}$ & $0.0425^{\star *}$ & $0.0448^{* *}$ \\
\hline & -0.8 & -0.84 & & & -2.3 & -2.35 & -2.47 \\
\hline \multirow{2}{*}{$\mathrm{ORA}_{i, t-1}$} & $-0.0323^{\star}$ & $-0.0316^{*}$ & & & $0.0317^{\star}$ & $-0.0327^{\star}$ & $0.032^{* *}$ \\
\hline & $(-1.69)$ & $(-1.65)$ & & & -1.66 & $(-1.71)$ & -1.68 \\
\hline \multirow{2}{*}{$\mathrm{LEV}_{i, t-1}$} & $0.105^{* * *}$ & $0.101^{* * *}$ & $-0.0368^{*}$ & $-0.0398^{*}$ & $0.106^{* * *}$ & $0.105^{* * *}$ & $0.1000^{* * *}$ \\
\hline & -5.17 & -4.95 & $(-1.89)$ & $(-1.94)$ & -5.24 & -5.17 & -4.94 \\
\hline \multirow{2}{*}{$\mathrm{SOE}_{i, t-1}$} & $0.201^{* * *}$ & $0.212^{\star * *}$ & $-0.0111^{* * *}$ & $-0.0177^{* * *}$ & $0.198^{* * *}$ & $0.201^{* * *}$ & $0.213^{* * *}$ \\
\hline & -6.7 & -7.03 & $(-3.32)$ & $(-3.26)$ & -6.59 & -6.71 & -7.05 \\
\hline \multirow{2}{*}{$\mathrm{EBD}_{i, t-1}$} & 0.0126 & 0.0106 & $-0.0283^{\star \star}$ & $-0.0273^{\star *}$ & 0.014 & 0.013 & 0.011 \\
\hline & -1.01 & -0.85 & $(-2.14)$ & $(-2.12)$ & -1.12 & -1.04 & -0.88 \\
\hline \multirow{2}{*}{$\operatorname{SIZE}_{i, t-1}$} & $-0.142^{\star * *}$ & $-0.141^{* * *}$ & $0.271^{* * *}$ & $0.271^{* * *}$ & $-0.14^{\star * *}$ & $-0.138^{\star * *}$ & $-0.137^{\star * *}$ \\
\hline & $(-7.00)$ & $(-6.99)$ & -4.98 & -4.98 & $(-6.9)$ & $(-6.8)$ & $(-6.8)$ \\
\hline \multirow{2}{*}{ GROWTH $_{i, t-1}$} & $0.0445^{\star * *}$ & $0.0485^{\star \star \star}$ & $0.155^{\star * *}$ & $0.154^{* * *}$ & $0.04^{\star *}$ & $0.0416^{\star *}$ & $0.0456^{* * *}$ \\
\hline & -2.59 & -2.82 & -4.2 & -4.14 & -2.34 & -2.44 & -2.67 \\
\hline \multirow{2}{*}{$\mathrm{ROE}_{i, t-1}$} & & & $0.0137^{* *}$ & $0.0138^{\star *}$ & & & \\
\hline & & & -2.33 & -2.14 & & & \\
\hline \multirow{2}{*}{$\mathrm{PB}_{i, t-1}$} & & & -0.0643 & -0.0648 & & & \\
\hline & & & $(-0.14)$ & $(-1.48)$ & & & \\
\hline \multirow{2}{*}{ TURN $_{i, t-1}$} & & & -0.0207 & -0.0224 & & & \\
\hline & & & $(-0.5)$ & $(-0.54)$ & & & \\
\hline \multirow{2}{*}{ cons } & $-0.092^{\star * *}$ & $-0.0748^{\star * *}$ & $-1.766^{* * *}$ & $-1.779^{\star * *}$ & $-0.111^{\star * *}$ & $-1.113^{* * *}$ & $-0.0953^{* * *}$ \\
\hline & $(-5.05)$ & $(-3.96)$ & $(-6.32)$ & $(-6.83)$ & $(-6.00)$ & $(-6.1)$ & $(-5.00)$ \\
\hline Year & YES & YES & YES & YES & YES & YES & YES \\
\hline Industry & YES & YES & YES & YES & YES & YES & YES \\
\hline $\mathrm{N}$ & 5188 & 5188 & 5188 & 5188 & 5188 & 5188 & 5188 \\
\hline Adj_R ${ }^{2}$ & 0.1695 & 0.1536 & & & 0.1572 & 0.1802 & 0.1932 \\
\hline $\begin{array}{l}\text { Likelihood } \\
\text { ratio }\end{array}$ & & & $243.6427^{\star * *}$ & $263.2546^{* * *}$ & & & \\
\hline
\end{tabular}


executives and affecting the cognitive path of executives. And only the incentives of restricted stocks will significantly affect executives' overconfidence, and stock options have no significant impact on them. The overconfidence of executives will make managers tend to overestimate future cash inflows and underestimate the discount rate of projects when analyzing investment projects, resulting in the illusion that the project's net present value is too large. Rational managers have a stronger willingness to invest and expand. When the investment scale exceeds a certain threshold, it will show excessive investment and damage the company's value.

Equity incentives have a mitigating effect on the direct effect of excessive investment, while equity incentives have a deteriorating effect on the indirect effects of over-confidence of executives on excessive investment. The direct and indirect effects of equity incentives are opposite, so executives are overconfident. Equity incentives and corporate over-investment play a special mediating effect-the cover effect. The above explanation shows that the equity incentive plan will affect the investment of the enterprise by affecting the psychological factors of the manager. Therefore, the company should also consider the possible impact on the executive psychology when formulating the equity incentive plan, and the senior management's psychology through the precise design of the incentive system. Deviation control is within a reasonable range to maximize the incentive effect of equity, thereby promoting the improvement of corporate performance.

In order to test the robustness of the above conclusions, the paper carries out the following tests: 1) changing the measurement method of key variables, and testing the robustness of the above results by changing the measurement method of executive equity incentive variables. EI_ALL ${ }_{i, t}$ Represents the company's total number of executive equity incentives/company total equity at the beginning of the year, including stock options and restrictions on new stocks, and also considers the actual age of the equity incentive program as described above. EI_RS $\mathrm{R}_{i, t}$ indicates the company's total number of executive-restricted stock incentives/company total equity at the beginning of the year, EI_OP ${ }_{i, t}$ indicates the company's total number of executive stock option incentives/company total equity at the beginning of the year. 2) Using the propensity score matching method to match the relationship between executive equity incentives and executive overconfidence, and the relationship between executive equity incentives and corporate inefficient investment. The results of the above robustness test are not substantially different from the above, so this paper believes that the previous conclusions are more stable.

\section{Conclusions}

Implementation of equity incentives for executives can lead executives to over-confidence, and this role is different for companies with different levels of investment. Insufficient investment in enterprises is mainly caused by the risk aversion characteristics of senior executives and the financing constraints of 
enterprises. The overconfidence of executives caused by executives' equity incentives will correct the risk aversion characteristics of executives and encourage executives to improve their investment level. In order to alleviate the phenomenon of insufficient investment, the overconfidence plays an intermediary role in executive equity incentives and corporate investment insufficiency, and considers the direct influence path of equity incentives to improve the investment level of enterprises by alleviating corporate financing constraints. Executives' overconfidence plays a part in the intermediary role between the two. Over-investment in enterprises is mainly caused by agency problems between shareholders and managers. Confidence will make managers tend to overestimate future cash inflows and underestimate the discount rate of projects when analyzing investment projects, resulting in the illusion that the project's net present value is too large, and overconfident managers versus rational managers. In the case of a stronger investment expansion intention, when the investment scale exceeds a certain threshold, it will manifest as excessive investment, thereby damaging the company's value. Equity incentives have a mitigating effect on the direct effect of excessive investment, while equity incentives have a deteriorating effect on the indirect effects of over-confidence of executives on excessive investment. The direct and indirect effects of equity incentives are opposite, so executives are overconfident. Equity incentives and corporate over-investment play a special mediating effect-the cover effect. In addition, the paper also proves that the incentive effect of restricted stocks is significantly higher than the incentive effect of stock options.

In summary, the over-confidence of executives caused by the granting of executive equity incentives is different for companies with different investment status. For under-investment companies, it can enhance the efficiency of executive equity incentives for enterprises. The optimization effect, while for over-investment enterprises, will weaken the optimization effect of executive equity incentives on corporate investment efficiency. Therefore, not only in the design of the program, we should pay attention to the impact of the implementation of equity incentives on executive psychology, but also effectively use or evade the impact of executive equity incentives in combination with the company's specific investment situation. The tendency of managerial overconfidence that may be caused by the implementation of equity incentives cannot be completely regarded as a factor that damages the value of the company. Over-confidence of under-investment executives is conducive to managers taking more active actions for over-investment. Enterprises should avoid the loss of corporate value caused by over-confidence of executives, but it is almost impossible to completely eliminate the negative impact of managers' overconfidence on company decision-making, and only to a certain extent contain the negative of managers' overconfidence. Effect, therefore, is particularly necessary to establish a sound corporate governance mechanism, effectively playing the decision-making and supervision functions of the board of directors, and improving the supervision mechanism of the board 
of directors and management by the shareholders' meeting. When implementing the equity incentive plan, the company should consider whether the company's existing governance structure can effectively curb the overconfidence and corresponding behaviors that managers may generate.

\section{Conflicts of Interest}

The author declares no conflicts of interest regarding the publication of this paper.

\section{References}

[1] Chu, E.Y. and Song, S.I. (2012) Executive Compensation, Earnings Management and over Investment in Malaysia. Earnings Management and Over Investment in Malaysia (May 4, 2012).

[2] Sawers, K., Wright, A. and Zamora, V. (2011) Does Greater Risk-Bearing in Stock Option Compensation Reduce the Influence of Problem Framing on Managerial Risk-Taking Behavior? Behavioral Research in Accounting, 23, 185-201. https://doi.org/10.2308/bria.2011.23.1.185

[3] Shen, H.H. and Zhang, H. (2012) CEO Risk Incentives and Firm Performance Following R\&D Increases. Journal of Banking \& Finance, 37, 1176-1194. https://doi.org/10.1016/j.jbankfin.2012.11.018

[4] Chen, X.D. and Zhou, J.N. (2014) Research on the Relationship between Executive Equity Incentive and R \& D Expenditure Level of the Company-Empirical Evidence from A-Share Market. Securities Market Guide, No. 2, 33-41.

[5] Erkens, D.H. (2011) Do Firms Use Time-Vested Stock-Based Pay to Keep Research and Development Investments Secret? Journal of Accounting Research, 49, 861-894. https://doi.org/10.1111/j.1475-679X.2011.00418.x

[6] Meyer, M., Milgrom, P. and Roberts, J. (1992) Organizational Prospects, Influence Costs, and Ownership Changes. Journal of Economics \& Management Strategy, 1, 9-35. https://doi.org/10.1111/j.1430-9134.1992.00009.x

[7] Aghion, P., Van Reenen, J. and Zingales, L. (2013) Innovation and Institutional Ownership. The American Economic Review, 103, 277-304. https://doi.org/10.1257/aer.103.1.277

[8] Myers, S.C. and Majluf, N.S. (1984) Corporate Financing and Investment Decisions When Firms Have Information That Investors Do Not Have. Journal of Financial Economics, 13, 187-221. https://doi.org/10.1016/0304-405X(84)90023-0

[9] Wang, Y.N. (2011) Research on the Impact of Executive Incentives on R\&D Investment-An Empirical Test Based on Listed Companies in China's Manufacturing Industry. Science of Science Research, 29, 1071-1078.

[10] Sun, J., Zhou, H.G. and Li, Q.J. (2016) Equity Incentives and Enterprise R\&D Investment-An Empirical Analysis Based on PSM. Economy of the South, 34, 63-79.

[11] Gormley, T.A., Matsa, D.A. and Milbourn, T. (2013) CEO Compensation and Corporate Risk: Evidence from a Natural Experiment. Journal of Accounting and Economics, 56, 79-101. https://doi.org/10.1016/j.jacceco.2013.08.001

[12] Hayes, R.M., Lemmon, M. and Qiu, M. (2012) Stock Options and Managerial Incentives for Risk Taking: Evidence from FAS 123R. Journal of Financial Economics, 105, 174-190. https://doi.org/10.1016/j.jfineco.2012.01.004 
[13] Croci, E. and Petmezas, D. (2015) Do Risk-Taking Incentives Induce CEOs to Invest? Evidence from Acquisitions. Journal of Corporate Finance, 32, 1-23. https://doi.org/10.1016/j.jcorpfin.2015.03.001

[14] Zhang, D.L. and Wang, Y.H. (2016) Equity Incentives, Property Rights and Investment Cash Flow Sensitivity of Executives. Securities Market Herald, No. 5, 18-24, 31.

[15] Gervais, S., Heaton, J.B. and Odean, T. (2000) Capital Budgeting in the Presence of Managerial Overconfidence and Optimism.

[16] Gervais, S., Heaton, J.B. and Odean, T. (2011) Overconfidence, Compensation Contracts and Capital Budgeting. The Journal of Finance, 66, 1735-1777.

[17] Zhuang, X. and Wang, J. (2010) Research on Dynamic Excitation Contract Based on Overconfidence and Supervision Mechanism. Journal of Systems Engineering, 25, 642-650.

[18] Chen, J. and Liu, S. (2012) Research on the Impact of Managerial Salary on Overconfidence-Based on Empirical Evidence of Shenzhen A-Share Listed Companies. East China Economic Management, No. 9, 122-125.

[19] Croci, E. and Petmezas, D. (2015) Do Risk-Taking Incentives Induce CEOs to Invest? Evidence from Acquisitions. Journal of Corporate Finance, 32, 1-23.

[20] Brown, R. and Sarma, N. (2007) CEO Overconfidence, CEO Dominance and Corporate Acquisitions. Journal of Economics \& Business, 59, 358-379. https://doi.org/10.1016/j.jeconbus.2007.04.002

[21] Zhang, Z. (2008) An Empirical Study of the Impact of Internal Compensation Gap on Organization's Future Performance. Accounting Research, No. 9, 81-87.

[22] Jiang, F., Zhang, M., Lu, Z., et al. (2009) Overconfidence, Corporate Expansion and Financial Distress in Managers. Economic Research, No. 1, 131-143.

[23] Jensen, M.C. (1986) Agency Cost of Free Cash Flow, Corporate Finance, and Takeovers. Corporate Finance, and Takeovers. American Economic Review, 76, 323-329.

[24] Ghosh, A., Moon, D. and Tandon, K. (2007) CEO Ownership and Discretionary Investments. Journal of Business Finance \& Accounting, 34, 819-839. https://doi.org/10.1111/j.1468-5957.2007.02011.x

[25] Hao, Y. and Liu, X. (2009) Capital Investment, Interest Capture and Squeezing Effect. Management World, 5, 128-144.

[26] Carpenter, J.N. (2000) Does Option Compensation Increase Managerial Risk Appetite? The Journal of Finance, 55, 2311-2331. https://doi.org/10.1111/0022-1082.00288

[27] Lerner, J. and Wulf, J. (2007) Innovation and Incentives: Evidence from Corporate R\&D. The Review of Economics and Statistics, 89, 634-644. https://doi.org/10.1162/rest.89.4.634

[28] Wu, L., Zhang, Y. and Zhang, T. (2015) Senior Management Term, R\&D Expenditure and Enterprise Investment Efficiency-Evidence from China's A-Share Capital Market. Journal of Nanjing Audit University, No. 5, 56-68 + 94.

[29] Lin, C. and Lin, Y. (2014) Background Characteristics of Top Management and Enterprise Investment Efficiency: Empirical Evidence from Chinese Listed Companies. Journal of Xiamen University (Philosophy and Social Sciences), No. 2, 100-109.

[30] Wang, X., Zhang, M. and Yu, F. (2008) Managerial Overconfidence and Alienation of Corporate Investment Behavior: Empirical Evidence from China's Securities Market. Nankai Management Review, 11, 77-83. 
[31] Li, Y. (2014) Over-Investment in the Company Stems from Managerial Agency or Overconfidence. World Economy, No. 12, 95-117.

[32] Ma, R., Li, Y., Yang, Y., et al. (2012) Over-Confidence, Over-Investment Behavior and Governance Mechanism of Corporate Managers-Evidence from Chinese Listed Companies. Securities Market Herald, 6, 38-43.

[33] Wen, Z. and Ye, B. (2014) Analysis of Mediating Effect: Development of Methods and Models. Advances in Psychological Science, No. 5, 731-745.

[34] Bergstresser, D. and Philippon, T. (2006) CEO Incentives and Earnings Management. Journal of Financial Economics, 80, 511-529. https://doi.org/10.1016/j.jfineco.2004.10.011

[35] Richardson, S. (2006) Over-Investment of Free Cash Flow. Review of Accounting Studies, 11, 159-189. https://doi.org/10.1007/s11142-006-9012-1 